\title{
Study of the process of preservation of insects of the Coccinellidae family - agents of biological protection of agricultural plants against pests
}

\author{
Barkar V. ${ }^{1}$, Molchanova . $^{2}$ \\ Engineeringand Technological Institute «Biotechnica» of NAAS \\ 26 Maiatska doroha Str., Khlibodarske, Biliaivka region, Odesa oblast, 67667, Ukraine \\ e-mail: ${ }^{1}$ barkarvitalij@gmail.com, ${ }^{2}$ lentochka.bio@gmail.com \\ ORCID: ${ }^{10000-0002-0965-9755, ~}{ }^{20000-0003-1049-7236 ~}$
}

\begin{abstract}
Goal. To investigate the effect of low temperatures on coccinellides at different stages of growth with the aim to develop and improve methods of their storage and transportation before introduction into agrocenoses. Methods. Adults and larvae were kept in thermostats at different temperatures. Results. The survival of adult insects of Propylea quatuordecimpunctata and Harmonia axyridis increased with gradual decrease in temperature. The survival of the adult insects of Coccinella septempunctata in the laboratory and natural populations was the same. Keeping adult insects of this species at temperatures of $5 \pm 0.5^{\circ} \mathrm{C}$ and $3 \pm 0.5^{\circ} \mathrm{C}$ showed the same results. The best survival of adult insects, as well as larvae of $P$. Quatuordecimpunctata of the $2 \mathrm{nd}$ and 4 th age groups was observed during storage at the temperature of $8 \pm 0.5^{\circ} \mathrm{C}$. Conclusions. During storage of adult insects of Harmonia axyridis and Propylea quatuordecimpunctata for 30 days, if the temperature was reduced gradually, survival was increased. Breeding insects of Coccinella septempunctata in the laboratory did not affect the survival of adult insects during storage. The comparison was made with the insects of the natural population. The results of storage of insects of the natural population at the temperature of $5 \pm 0.5^{\circ} \mathrm{C}$ and $3 \pm 0.5^{\circ} \mathrm{C}$ did not differ significantly. Insects of Propylea quatuordecimpunctata in the adult stage were more vulnerable to lower temperatures. The number of beetles that survived after being kept at 5 $\pm 0.5^{\circ} \mathrm{C}$ was lower than in the variant where the final storage temperature was $8 \pm 0.5^{\circ} \mathrm{C}$. It is recommended to store imago of Propylea quatuordecimpunctata at the temperature of $8 \pm 0.5^{\circ} \mathrm{C}$ in the ventilated container. Also, the temperature of $8 \pm 0.5^{\circ} \mathrm{C}$ was determined to be much better for storing Propylea quatuordecimpunctata larvae. Insects in the stage of larvae of the 4th age group can be kept at this temperature for 2 weeks without losses, larvae of the 2 nd age group - for 1 week with insignificant losses (6-7\%). The development of methods of storage of coccinellides can be a useful tool for reducing production costs and meeting the peak demand of farmers during the growing season.
\end{abstract}

Key words: coccinellides, laboratory population, storage, low temperatures. DOI: https://doi.org/10.31073/agrovisnyk202010-08

Coccinellidae, or ladybeetles (Coleoptera) are an important part of the biotope in various climatic zones. Most family members are predators and play an important role in regulating the number of plant pests. Beetles destroy aphids, leaflets, shields, thrips, ticks and other small arthropods, as well as scallops on the stage of eggs [1]. Ladybeetles can withstand the unfavorable conditions, capable of long-distance flights, characterized by high voracity. Due to these qualities, coccinellids have long been used for biological protection of plants and are among the most promising entomophages in modern biomedes [2]. In addition, predators are widely used for genetic research.

There are two methods of obtaining coccinellidae to protect plants from pests. The first, the oldest, is that insects are massively collected in natural biocenoses for their subsequent introduction into agrobiocenoses [3]. But this method is ineffective because it requires significant labor costs, but it does not make it possible to determine the targets before using the predator.

More perspective is the cultivation of coccinellidae under artificial conditions [4,5]. This makes it possible to develop a large number of beetles and use it to protect plants with entomoculture with controlled biological indicators. In addition, artificial breeding allows to carry out introductions of the jaws not only at the stage of the imago, but also at the stage of eggs and larvae. It should be added that the rapacity of insects in the juvenile stage is much higher. Migration ability of the imago is quite high, inevitably their movement beyond the intended area of use. The larvae do not leave the place of release and they have a speed of movement, especially in larvae I age. This makes it possible to use larvae in pest cells in the protection of plants.

Undeniable for the first method is the need for accumulation and long-term storage of coccinellidae. But for the second method of accumulation of biomaterials and their storage allows the organization of costeffective production with a flexible scheme of technological processes [6]. It should be noted that the primary 
task of breeding coccinellids is to protect crops from pests. Therefore, there is a need to use the laws of development and formation of entomophagous and their effective use in modern crop management systems, as well as to determine the optimal timing of biological drugs depending on the biology of harmful and beneficial organisms of agrobiocenoses [7]. In addition, account should be taken of the economic component of breeding predators. The optimum temperature range for propagation and development of insects is $20-25^{\circ} \mathrm{C}$ [8]. Providing such parameters in conditions of temperate climate is most easy in the warm season (from April to October). In the cold period, maintenance of the necessary climatic conditions for breeding beetles requires significant energy consumption. Working out of storage methods allows to reduce the production cost. The most common method of storage is the use of reduced temperatures [9]. Storing insects enables to synchronize breeding operations, to accumulate predators of the necessary stage of development [10]. Usually the most adapted to low temperatures coccinellidae in the stage of the imago. For species living in regions with temperate climate characteristic natural property to fall into diapause in the cold seasons. With the advent of cold imago for winter, find cozy places under stones, in leafy litter, under the bark of trees, in household and living spaces [11]. Based on knowledge about the ability of coccinellidae to enter into anabiosis under adverse conditions, studies are under way to determine the most effective methods for preserving the imago for further use $[6,8,10]$.

Accumulation of the imago does not always make it possible to obtain a sufficient number of insects in the juvenile period in the required term. Therefore, research is being carried out on the conservation of beetles at various stages of development [9, 12-14].

The most insipid and least vulnerable are larvae of the fourth age [4]. But the term of their development until the pupation is short. As an example, the development of larvae of different age groups Coccinella septempunctata L. and Propylea quatuordecimpunctata L. in laboratory conditions [15] can be inferred. The development of larvae of a $C$. septempunctata is: the first age - 2-3 days; second age - 2-4 days; third age 1-2 days; fourth age $-3-4$ days. The development of $\quad P$. quatuordecimpunctata larvae continues: the first age $-2-3$ days; second age $-2-3$ days; third age $-2-3$ days; fourth age -2 days. The use of ladybeetles in the stage of larvae of younger ages can significantly increase the useful life in agrobiocenoses. Use coccinelide larvae that allow you to constantly reduce pesticides per load. As an example in comparison with difference entomophagous: aphids on the surface of solar sunflowers more than 1:25 efficiency of action of predators makes $68 \%$ that does inexpedient chemical breaks. This allows to use environmentally friendly products [16].

The purpose of research. To study the influence of lower temperatures on coccinellidae of different stages of development, which will enable to develop and improve methods of their storage.

Materials and methods. The studies were carried out with the following species common in Ukraine: Coccinella septempunctata (Linnaeus, 1758) 7th generation laboratory population; Propylea quatuordecimpunctata (Linnaeus 1758) of the 9th generation of the laboratory population and the Harmonia axyridis (Pallas, 1773) of the 7th generation of the laboratory population. In conducting the experiments, insects were also used in the stage of the imago of the Coccinella septempunctata natural population, which were collected in the Khlibodarskoye settlement, Odessa region, methods of mowing and manual harvesting. In research, paper packages, Petri dishes, and food polyethylene bags were used (Fig. 1).

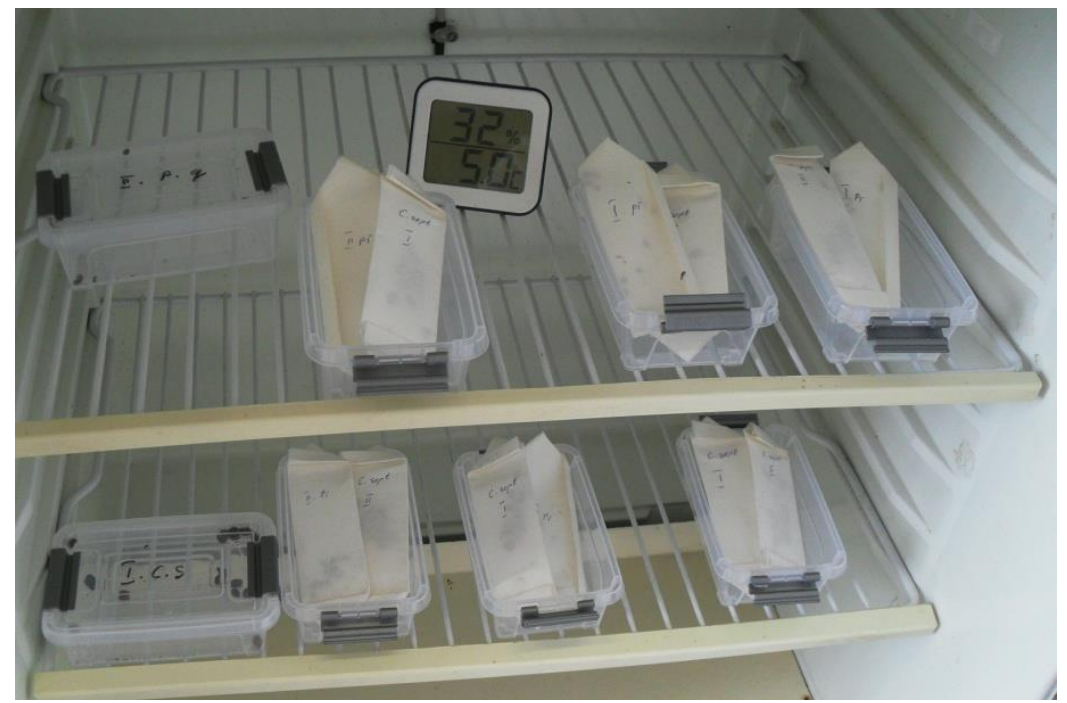

Fig. 1. Storage of imago coccinellidae in a thermostat 
Before conducting research, insects were grown in cage at a temperature of $23-25^{\circ} \mathrm{C}$. Before the study, the threshold of activity was determined, that is, the highest temperature at which the larvae and the imago enter the state of full evaluation. For this, the temperature in the thermostat, where the predators were kept, gradually decreased from $15^{\circ} \mathrm{C}$ to $2-3^{\circ} \mathrm{C}$ every hour. Subsequently, insects were stored in thermostats at temperatures of $8,0 \pm 0,5^{\circ} \mathrm{C}$ and $5,0 \pm 0,5^{\circ} \mathrm{C}$ for four weeks without feed. Every seven days, the number of live and dead larvae in cups was counted. To ensure the death of the larvae, insects without signs of life were kept in separate Petri dishes for two hours.

It is determined that larvae of predators lose mobility, and imago fall into the state of physiological calm at an air temperature below $9^{\circ} \mathrm{C}$. Therefore, for the research, the air temperature at which the storage was carried out was $5^{\circ} \mathrm{C}$ and $8^{\circ} \mathrm{C}$. The research was carried out in cold-thermostats. The temperature deviation in the volume of the thermostat chambers was $\pm 0,5^{\circ} \mathrm{C}$. Various options were used to keep predators at reduced temperatures.

When carrying out experiments imago was placed in packages of filter paper and in packages that were wrapped in food polyethylene. Experiments were performed in triple repeats.

Schemes of research on imago are given in the tables (table 1-3).

\section{Storage of Harmonia axyridis in the stage of the imago}

\begin{tabular}{|c|c|c|c|}
\hline \multirow{2}{*}{ Variant } & 1 day & 2 day & $3-302$ day \\
\cline { 2 - 4 } & \multicolumn{3}{|c|}{ temperature, ${ }^{\circ} \mathrm{C}$} \\
\hline I & $5 \pm 0,5$ & $5 \pm 0,5$ & $5 \pm 0,5$ \\
\hline II & $15 \pm 0,5$ & $5 \pm 0,5$ & $5 \pm 0,5$ \\
\hline III & $15 \pm 0,5$ & $10 \pm 0,5$ & $5 \pm 0,5$ \\
\hline
\end{tabular}

Storage of $\mathrm{H}$. axyridis occurred at different temperature regimes: I - during the study storage temperature $5 \pm 0,5^{\circ} \mathrm{C}$; II - the first day storage temperature $15 \pm 0,5^{\circ} \mathrm{C}$, from the second day $-5 \pm 0,5^{\circ} \mathrm{C}$; III - first day storage temperature $15 \pm 0,5^{\circ} \mathrm{C}$, second day $-10 \pm 0,5^{\circ} \mathrm{C}$, from the third day $-5 \pm 0,5^{\circ} \mathrm{C}$.

\section{Storage of Coccinella septempunctata at the stage of the imago}

\begin{tabular}{|c|c|c|c|c|c|}
\hline \multirow{2}{*}{ Variant } & \multirow{2}{*}{ Origin } & 1 day & 2 day & 3 day & 4- 30 day \\
\hline & & \multicolumn{4}{|c|}{ temperature, ${ }^{\circ} \mathrm{C}$} \\
\hline I & $\begin{array}{l}\text { Laboratory, age imago } 30- \\
45 \text { days }\end{array}$ & $12 \pm 0,5$ & $8 \pm 0,5$ & $5 \pm 0,5$ & $5 \pm 0,5$ \\
\hline II & Natural population & $12 \pm 0,5$ & $8 \pm 0,5$ & $5 \pm 0,5$ & $5 \pm 0,5$ \\
\hline III & Natural population & $12 \pm 0,5$ & $8 \pm 0,5$ & $5 \pm 0,5$ & $3 \pm 0,5$ \\
\hline
\end{tabular}

The influence of the lower temperatures on the imago of the laboratory population of $C$. septempunctata and the insects isolated from nature by the approaching decrease of temperatures was compared: I, II - the first day storage temperature $-12 \pm 0,5^{\circ} \mathrm{C}$, the second day $-8 \pm 0,5^{\circ} \mathrm{C}$, from the third days $-5 \pm 0,5^{\circ} \mathrm{C}$. The third variant of the experiment, the insects from the natural population were kept under the scheme: the first day $12 \pm 0,5^{\circ} \mathrm{C}$, the second day $-8 \pm 0,5^{\circ} \mathrm{C}$, the third day $-5 \pm 0,5^{\circ} \mathrm{C}$, from the fourth day $-3 \pm 0,5^{\circ} \mathrm{C}$.

\section{Storage of Propylea quatuordecimpunctata at the stage of the imago}

\begin{tabular}{|c|l|c|c|c|}
\hline \multirow{2}{*}{ Variant } & \multicolumn{1}{|c|}{ Storage method } & 1 day & 2 day & $3-30$ day \\
\cline { 3 - 5 } & & \multicolumn{3}{|c|}{ temperature, ${ }^{\circ} \mathrm{C}$} \\
\hline I & Package of filter paper & $5 \pm 0,5$ & $5 \pm 0,5$ & $5 \pm 0,5$ \\
\hline II & Package of filter paper & $12 \pm 0,5$ & $8 \pm 0,5$ & $5 \pm 0,5$ \\
\hline III & $\begin{array}{l}\text { Package of filter paper, wrapped in food } \\
\text { cellophane }\end{array}$ & $12 \pm 0,5$ & $8 \pm 0,5$ & $5 \pm 0,5$ \\
\hline IV & Package of filter paper & $12 \pm 0,5$ & $8 \pm 0,5$ & $8 \pm 0,5$ \\
\hline
\end{tabular}




\begin{tabular}{|l|l|c|c|c|}
\hline $\mathrm{V}$ & Package of filter paper & $8 \pm 0,5$ & $8 \pm 0,5$ & $8 \pm 0,5$ \\
\hline
\end{tabular}

Storage of imago $P$. Quatuordecimpunctata occurred under the following temperature regimes: I - from the first day at a storage temperature of $5,0 \pm 0,5^{\circ} \mathrm{C}$; II, III - the first day storage temperature $-12,0 \pm 0,5^{\circ} \mathrm{C}$, the second day $-8,0 \pm 0,5^{\circ} \mathrm{C}$, from the third day $-5,0 \pm 0,5^{\circ} \mathrm{C}$; IV - the first day is $12,0 \pm 0,5^{\circ} \mathrm{C}$, from the second day $-8,0 \pm 0,5^{\circ} \mathrm{C}, \mathrm{V}-$ at a constant storage temperature $-8,0 \pm 0,5^{\circ} \mathrm{C}$. Insects were kept in package of filter paper and in package wrapped with food cellophane.

Investigations with predators in the juvenile stage were conducted with the laboratory population of $P$. Quatuordecimpunctata using the second and fourth age groups of larvae. The following constant storage temperatures were studied: $5,0 \pm 0,5^{\circ} \mathrm{C}, 8,0 \pm 0,5^{\circ} \mathrm{C}$. In the studies, Petri dishes were used, which contained 15 larvae.

Research results. The survival of the imago $H$. axyridis after a gradual and sharp introduction into the state of physiological evaluation (Table 1) is uneven. It should be noted that this indicator between the first and second variants is not significant. The first two are different from the third variant. Survival in it after 30 days of retention at low temperatures was $79,5 \%$ (Fig. 2). Gradual lowering of the temperature in a step of $10^{\circ} \mathrm{C}$ slightly increased survival compared with a sharp drop to $5,0 \pm 0,5^{\circ} \mathrm{C}$. The gradual decrease in temperature of every day at $5^{\circ} \mathrm{C}$ significantly influenced the number of surviving insects.

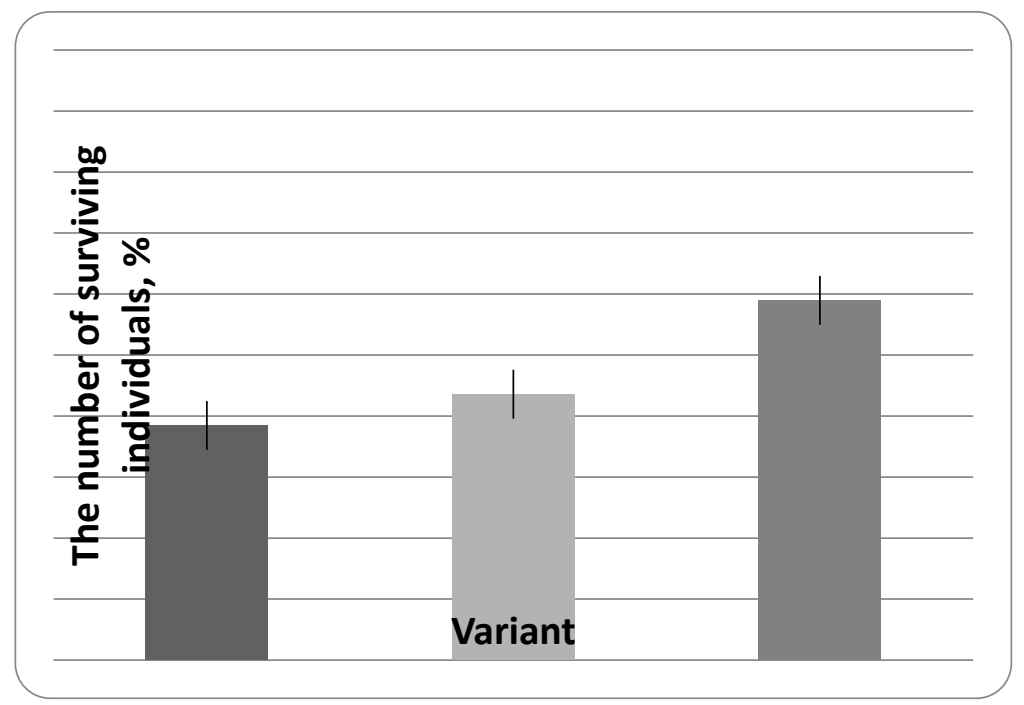

Fig. 2. The number of Harmonia axyridis imago that survived after 30 days of retention at reduced temperatures

The characteristics of the variants are given in Table 1.

With a gradual decrease in temperature (Table 2) there is no significant difference in the survival of the Imago $C$. Septempunctata in the laboratory population and withdrawn from nature after 30 days (option I, II). Also, the survival rate of insects in the natural population after the final reduction of temperatures up to $5 \pm 0,5^{\circ} \mathrm{C}$ and $3 \pm 0,5^{\circ} \mathrm{C}$ (variant III) does not differ. In all variants, this figure was $94-96 \%$.

The survival of the imago $P$. Quatuordecimpunctata, in the first variant, where the temperature from the first day of storage was $5 \pm 0,5^{\circ} \mathrm{C}$ (Table 3), was ten percent lower than in the 2 nd variant, where the temperature gradually decreased to $5 \pm 0,5^{\circ} \mathrm{C}$ (Fig. 3). The lowest, $30 \%$, survival is observed in the third variant, where the insects were placed in packages of filter paper wrapped in food polyethylene, and the temperature drop also occurred gradually to $5,0 \pm 0,5^{\circ} \mathrm{C}$. Higher rates are observed in variants, where the final temperature was $8,0 \pm 0,5^{\circ} \mathrm{C}$. And again, a sharp drop in temperature to eight degrees ( $V$ variant) showed a worse $(60 \%)$ result than in the fourth variant, where the temperature drop occurred gradually. The survival in the fourth variant was the highest in experiment and amounted to $73,3 \%$. 


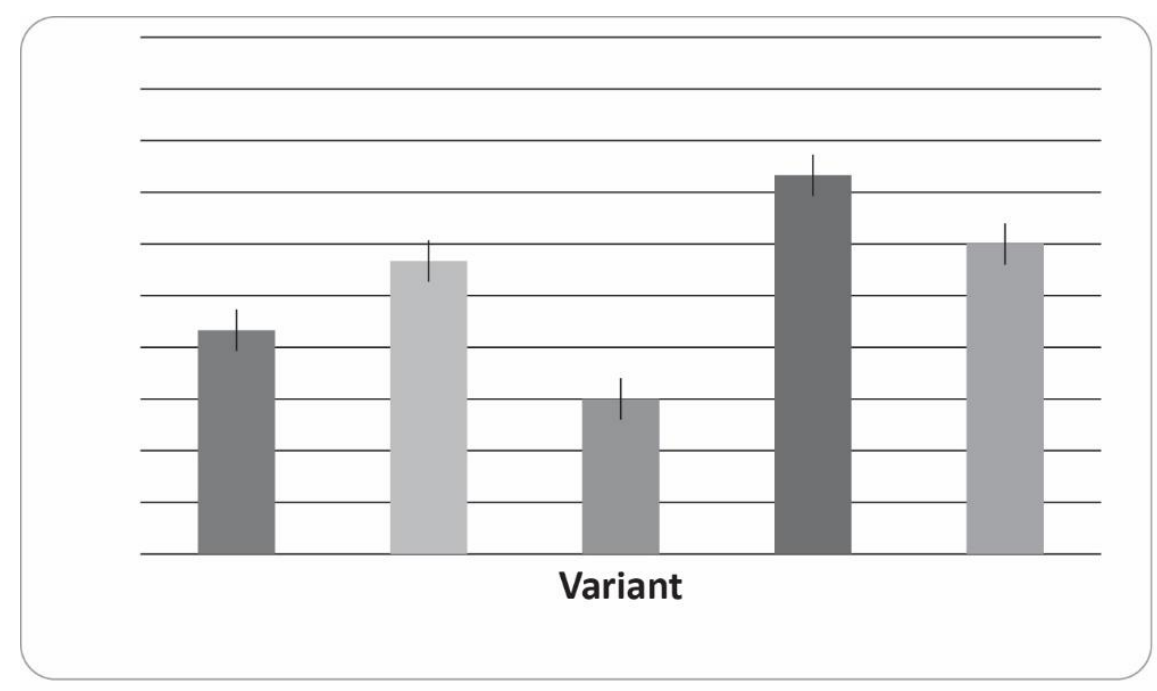

Fig. 3. Number of Imago Propylea quatuordecimpunctata, survived after 30 days of retention at reduced temperatures

Resistance of larvae of the second and fourth age groups at a temperature of $8,0 \pm 0,5^{\circ} \mathrm{C}$ exceeded the survival of the corresponding age groups at a temperature of $5,0 \pm 0,5^{\circ} \mathrm{C}$ (Fig. 4). During the first two weeks at both temperatures, the highest rates were observed in larvae of the fourth age. During this period, in the first variant, no insects died, while in the third variant, the survival rate was $91,7 \%$. It should be noted that after two weeks of storage, the mortality in both variants began to increase rapidly. Significantly lower were the results in variants where larvae of the second age group were kept at the same temperatures. But the trend persisted and the difference between the options was more significant. Already a week at a temperature of $8,0 \pm 0,5^{\circ} \mathrm{C}$ (variant II), the survival rate was $93,5 \%$ vs. $64,7 \%$ in IV variant, where insects were kept at a temperature of $5,0 \pm 0,5^{\circ} \mathrm{C}$. At 28 days, the number of insects surviving in the second version was $50 \%$, while in the fourth almost all insects died. It should be noted that after three weeks of storage at a temperature of $8 \pm 0,5^{\circ} \mathrm{C}$ survival of larvae of the second age group began to exceed the survival rate in the III variant, where insects of the fourth age group were kept at a temperature of $5,0 \pm 0,5^{\circ} \mathrm{C}$.

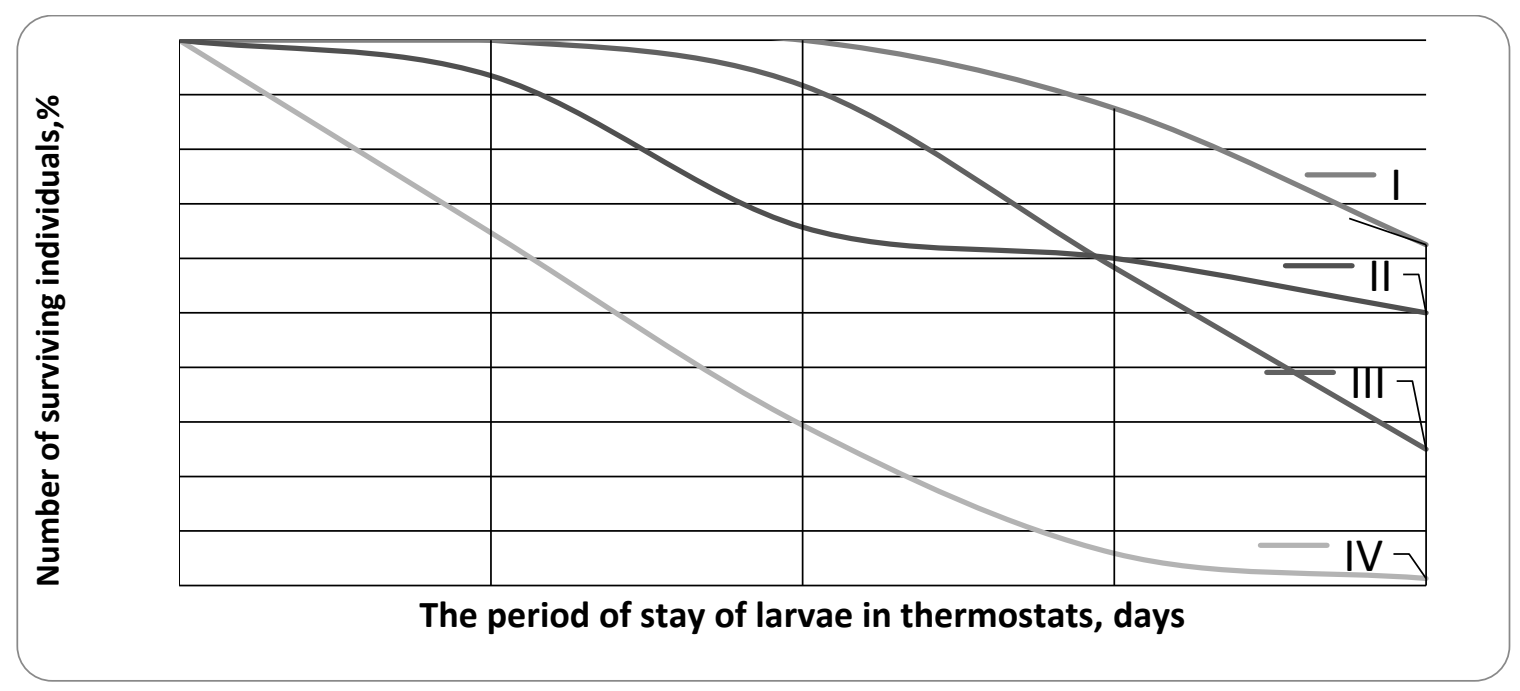

Fig. 4. Livestock survival Propylea quatuordecimpunctata at reduced temperatures: Variants: I - IV larvae, holding temperature $-8 \pm 0,5^{\circ} \mathrm{C}$; II - larvae of the second age, holding temperature $-8 \pm 0,5^{\circ} \mathrm{C}$; III - larvae of the IV age, holding temperature $-5 \pm 0,5^{\circ} \mathrm{C}$; IV - larvae of the 2nd age, holding temperature $-5 \pm 0,5^{\circ} \mathrm{C}$. 


\section{Conclusions}

As a result of the research, it was determined that during storage of the Imago Harmonia axyridis and Propylea quatuordecimpunctata for 30 days, if the temperature is lowered gradually, survival increases. This allows insects to adapt and avoid physiological stress. This method of storage requires further research, in which the temperature will change gradually with a smaller step and a longer term.

Breeding of Coccinella septempunctata in the laboratory did not affect survival of the imago during storage. The comparison was made with insects of the natural population. Results of storage of insects in the natural population at a temperature of $5,0 \pm 0,5^{\circ} \mathrm{C}$ and $3,0 \pm 0,5^{\circ} \mathrm{C}$ did not differ significantly. These temperatures are favorable for storing beetles within a month.

Propylea quatuordecimpunctata in the stage of the imago is more vulnerable to lowering of the temperature. The number of beetles that survived after holding at a temperature of $5,0 \pm 0,5^{\circ} \mathrm{C}$ was $20 \%$ lower than in the case where the final storage temperature was $8,0 \pm 0,5^{\circ} \mathrm{C}$. The use of a polyethylene package has led to the largest mortality among imago, which indicates the need for air exchange during storage. Therefore, it is recommended to store imago $P$. quatuordecimpunctata at a temperature of $8,0 \pm 0,5^{\circ} \mathrm{C}$ in ventilated containers.

Also, a significantly better determined temperature of $8,0 \pm 0,5^{\circ} \mathrm{C}$ for the storage of Propylea quatuordecimpunctata larvae. Insects in the stage of larvae of the fourth age group can be kept at that temperature for two weeks without losses, larvae of the second age group for one week with minor losses (67\%). Developing storage methods can be a useful tool for lowering the cost of production and meeting the peak demand of farmers in the growing season. The results of the study can be used for the accumulation of entomophagous in biofactories for more efficient use of beetles in crop production. Also, the peculiarities of storage of coccinellidae should be taken into account when transporting them to agrocenoses, the introduction of which is the main purpose of breeding ladybugs.

\section{References}

1. Mojib-Haghghadam, Z., Jalali Sendi, J., Zibaee, A., \& Mohaghegh, J. (2018). Suitability of Aphis gossypii Glover, Aphis fabae Scop. and Ephestia kuehniella Zeller eggs for the biology and life-table parameters of Adalia decempunctata (L.) (Coleoptera: Coccinellidae). Arch Biol Sci., 70(4). 737-747.

2. Sarwar, M. (2016). Biological Control to Maintain Natural Densities of Insects and Mites by Field Releases of Lady Beetles (Coleoptera: Coccinellidae). International Journal of Entomology and Nematology, 2(1), 021-026.

3. Savoyskaya, G.I. (1960). O zimovkah nekotoryih koktsinellid yugo-vostochnogo Kazahstana. [On the wintering of some coccinellid southeastern Kazakhstan]. Russian Journal of Zoology, XXXIX (6), 882-887. [in Russian].

4. Savoyskaya, G.I. (1991). Tlyovyie korovki. [Aphidophagous ladybird beetles]. Moscow: Agropromizdat. [in Russian].

5. Zlotin, A.Z. (1989). Tehnicheskaya entomologiya. [Technical Entomology]. Kyiv. Scientific thought. [in Russian].

6. Semyanov, V. P. (1996). Metodika razvedeniya i dlitelnogo hraneniya tropicheskogo vida koktsinellid Leis dimidiata (Fabr.) (Coleoptera, Coccinellidae). [Method of breeding and long-term storage of tropical species coccinellidae Leis dimidiata (Fabr.) (Coleoptera, Coccinellidae)]. Entomological Review, LXXV (3), 714-721. [in Russian].

7. Dolia, M. M., Yushchenko, L. P., Varchenko, T.P. (2018). Peculiarities of use of modern biological preparations for protection of agricultural culture from pests in the forest steppe and polissia of Ukraine. Agricultural microbiology, 27, 60-66. [in Ukrainian].

8. Papanikolaou, N. E., Milonas, P. G., Kontodimas, D. C., Demiris, N., \& Matsinos, Y.G. (2013). Temperature-Dependent Development, Survival, Longevity, and Fecundityof Propylea quatuordecimpunctata (Coleoptera: Coccinellidae). Annals of the Entomological Society of America, 106(2), 228-234.

9. Gagnea, I., Coderre, D. (2001). Cold Storage of Coleomegilla maculata larvae. Biocontrol Science and Technology, 11, 361-369.

10. Ruan, C. C., Du, W. M., Wang, X. M., Zhang, J. J., \& Zang, L. S. (2012). Effect of long-term cold storage on the fitness of pre-wintering Harmonia axyridis (Pallas). BioControl, 57, 95-102.

11. Hakimov, F.R., \& Muhitdinov, S.M. (2009). Abundance and biotopic distribution of wintering populations of coccinellid beetles (Coleoptera, Coccinellidae) in the Gissar Valley of Tajikistan. News of the Academy of Sciences of the Republic of Tajikistan. Department of Biological and Medical. Science, 2. Entomology, 22-28. [in Russian].

12. Hämäläinen, M., \& Markkula, M. (1977). Cool storage of Coccinella septempunctata and Adalia bipunctata (Col., Coccinellidae) eggs for use in the biological control in greenhouses. Annales agriculturae fenniae. Helsinki, 16, 132-136. 
13. Miller, J. C. (1995). A Comparison of Techniques for Laboratory Propagation of South American Ladybeetle, Eriopis connexa (Coleoptera: Coccinellidae). BioControl, 5, 462-465.

14. Katsarou, I., Margaritopoulos, J. T., Tsitsipis, J. A., Perdikis, D.Ch., \& Zarpas, K. D. (2005). Effect of temperature on development, growth and feeding of Coccinella septempunctata and Hippodamia convergens reared on the tobacco aphid, Myzus persicae nicotianae. BioControl, 50, 565-588.

15. Tyumaseva, Z.I. (2013). Coccinellidae of the Urals and from certain territories. Monograph. [Koktsinellidyi Urala i s opredelnyih territoriy]. Chelyabinsk. [in Russian].

16. Liashuk, N.I. (2009). Obgruntuvannia pryiomiv upravlinnia shkidlyvymy orhanizmamy pry formuvanni produktsii tekhnichnykh kultur [Justification of receptions pest management during formation products of industrial crops]. Odessa National Academy of Food Technologies. Scientific works, 36(1), 253-255. [in Ukrainian]. 